\title{
The house by the lake
}

\author{
C.A. Brebbia ${ }^{1} \& \mathrm{~J}_{\text {Gorst }}{ }^{2}$ \\ ${ }^{1}$ Wessex Institute of Technology, ${ }^{2}$ James Gorst Architects
}

\begin{abstract}
The paper describes the proposed building of an Ecohouse located alongside a small lake and against a steep slope. Managed woodland surrounds the site, which is accessed by existing driveways.

The design of the landscape accepts the land in this existing state and does not propose any formal area requiring additional work.

The whole design is in harmony with its surroundings. The philosophy of the design is to produce a low energy eco-friendly house which is as environmentally aware as it is architecturally distinguished. As such, it will serve as an example for the country house of the $21^{\text {st }}$ century.
\end{abstract}

\section{Introduction}

The brief was to design a house for the first author and his wife that responds to his academic needs as well as being a functional home. It is also a statement of their commitment to creating a type of architecture which is environmentally friendly and in harmony with its surroundings.

The shared objective of the team was to design and build a low-energy, sustainable home of distinguished architecture [1].

James Gorst Architects led the team which included the eminent environmental engineer, Max Fordham, ecologists and landscape architects, as well as consulting engineers and planners. Their aim was to design an ecofriendly house which can be a model for the future.

This paper describes the main aspects of the new design, ie:

- The Design Guidelines How the proposed site is ideally situated to the design of an eco-house and how the proposal relates to the new UK Planning Policy guidelines known as PPS7. 
- The Design Philosophy Setting up the requirements of the owners and in particular, their commitment to commission an eco-friendly house.

- Environmental Engineering The guideline was to produce an energy efficient building that can achieve a carbon neutral rating and consume as little energy as possible from non-renewable sources.

- $\quad$ The Structure The aim was to design a light structure with minimum impact on its environment. The contractor was to use vernacular materials.

The proposal, which has recently been rejected by the New Forest planners, is now under appeal and it is hoped that the Inspector in charge of the hearing will exhibit a more open-minded attitude to this important project.

\section{The design guidelines}

The house would be built in part of the nearly 20 hectares surrounding the existing Burley Hill House. The land is located on high ground and consists of mature woodlands. Burley Hill House is sited north-west of Burley, a popular and picturesque village in the heart of the New Forest.

The site of the proposed new house is an existing clearing in the deciduous woodland. The clearing is located on a south east facing slope some 15 metres below Burley Hill House and 15 metres in height above the centre of Burley village. The clearing contains a small lake on a leveled area within the overall slope, and is open-style grassland. The whole land has been improved under the supervision of The Forestry Commission. All woodlands at Burley Hill are managed in accordance with the plan of operations approved by The Commission. This includes thinning, replanting, species selection, habitat, diversification and management of all rides.

The Burley Hill estate lies within the settlement of Burley and is included within that conservation area. The village centre, with its full range of facilities and shops is only $700 \mathrm{~m}$ away. Thus, for an isolated house, the need to travel is much less than for the case of other country houses.

Planning permission was sought within the guidelines of the Special Planning Policy called PPS7, published in 2004. PPS7 encourages innovative design and its paragraph II summarizes the terms that need to be applied to any project. ie.

- Single house

- Isolated location

- Exceptional quality of design and engineering

- Innovative and groundbreaking in design, materials and methods of construction, as well as in protection and enhancement of the environment

- Significantly enhances the immediate setting

- Sensitivity to the characteristics of local areas 
Eco-Architecture: Harmonisation between Architecture and Nature 217

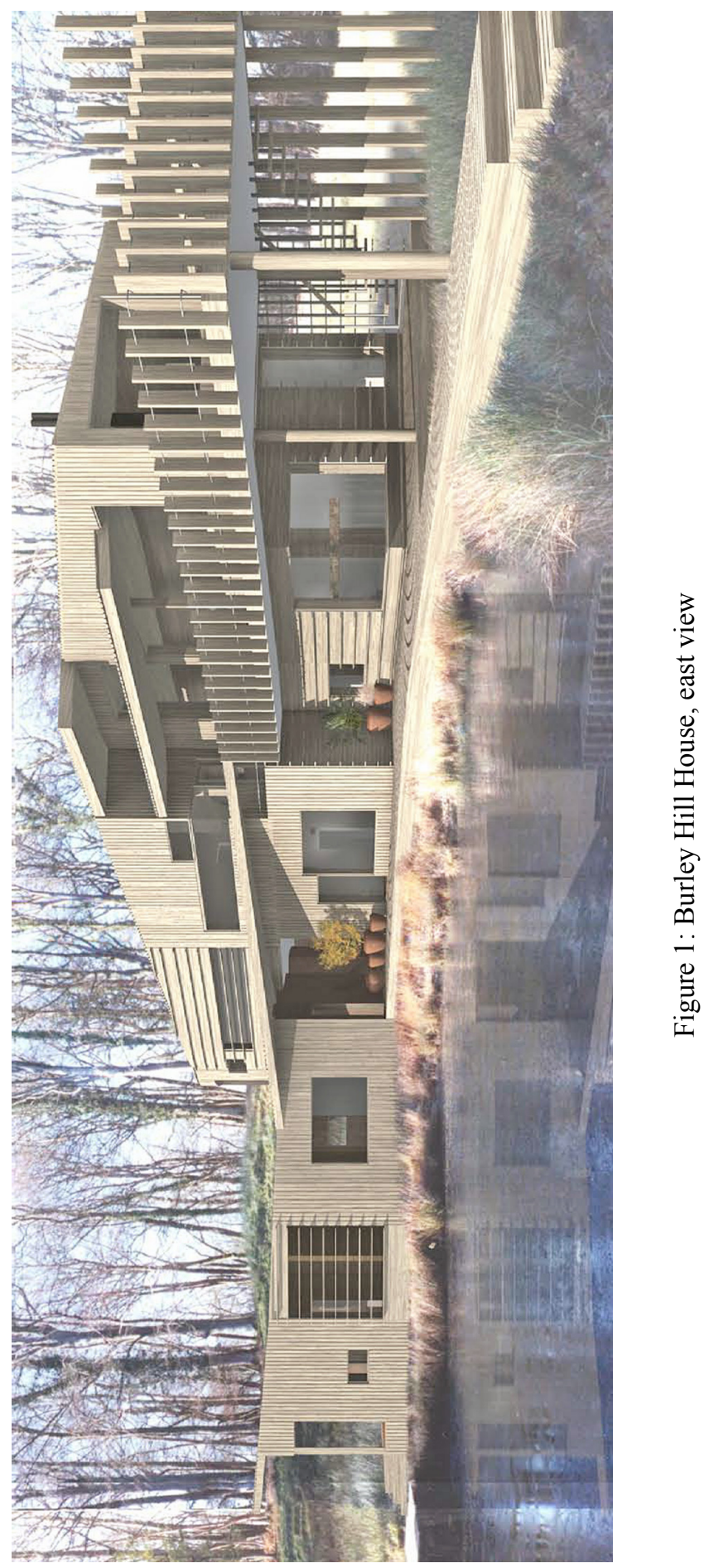

(4) WIT Transactions on The Built Environment, Vol 86, (C) 2006 WIT Press

1743-3509 (on-line) 


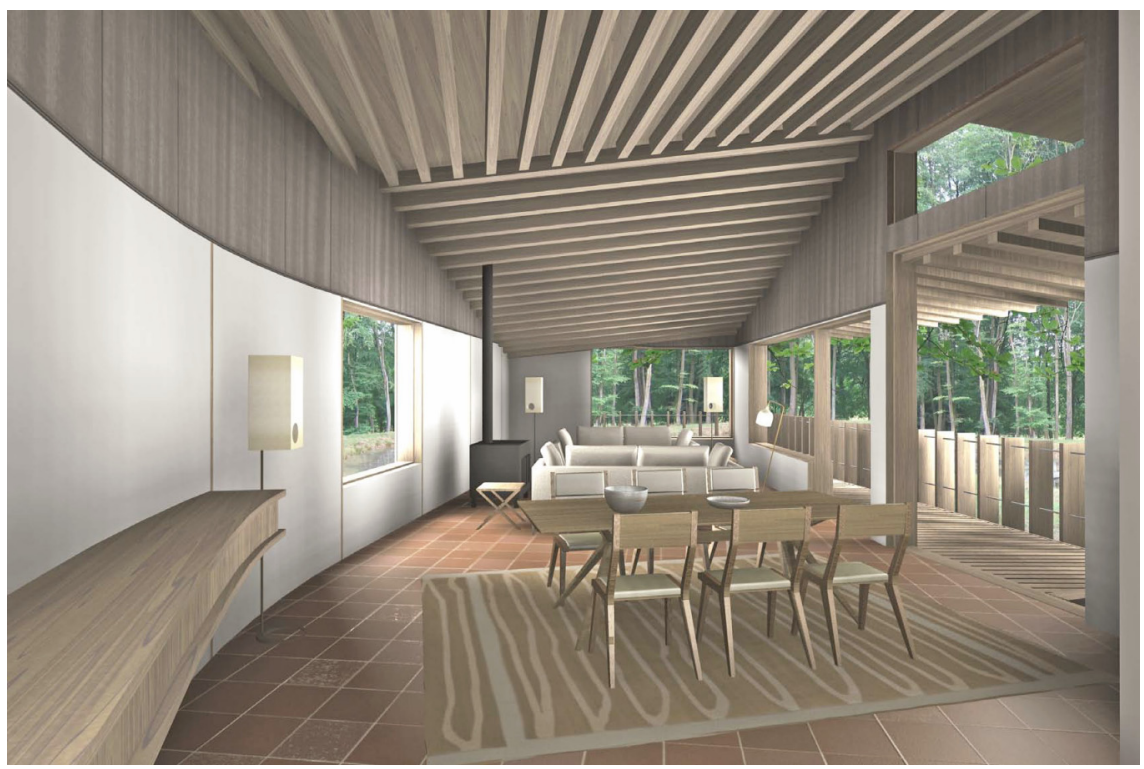

Figure 2: Interior view

\section{The design philosophy}

The owners of the proposed house required suitable accommodation for an academic and his wife as well as visiting family and guests. The brief was to develop a design in harmony with its environment in order to make a statement and point out a way towards a sustainable future. Hence the house is a demonstration of the commitment of the occupier to environmental and ecological issues [2].

Throughout the design, the environmental requirements are dominant. The house sits lightly on the land, not cutting into the slopes or scarring the terrain. Its construction exploits the vernacular of the New Forest, cob walls with clay extracted from the site, locally sourced timber for the structure and for cladding the facades.

The philosophy of a low energy, lightweight, bioretrogradable and demountable building means that the use of concrete has been excluded from the design. The complex facetted roof is covered in an eco-friendly recyclable membrane and dangerous chemicals have been avoided throughout the design.

The structure of the scheme has been developed by Alan Baxter Associates Consulting Engineers and the environmental strategy with Max Fordham, both eminent consultants. Similarly, the ecological aspect of the building has been assessed by Ecohomes Scheme [3] and the landscaping proposal set up by Hilary Martin of Integrated Design. 
Eco-Architecture: Harmonisation between Architecture and Nature 219

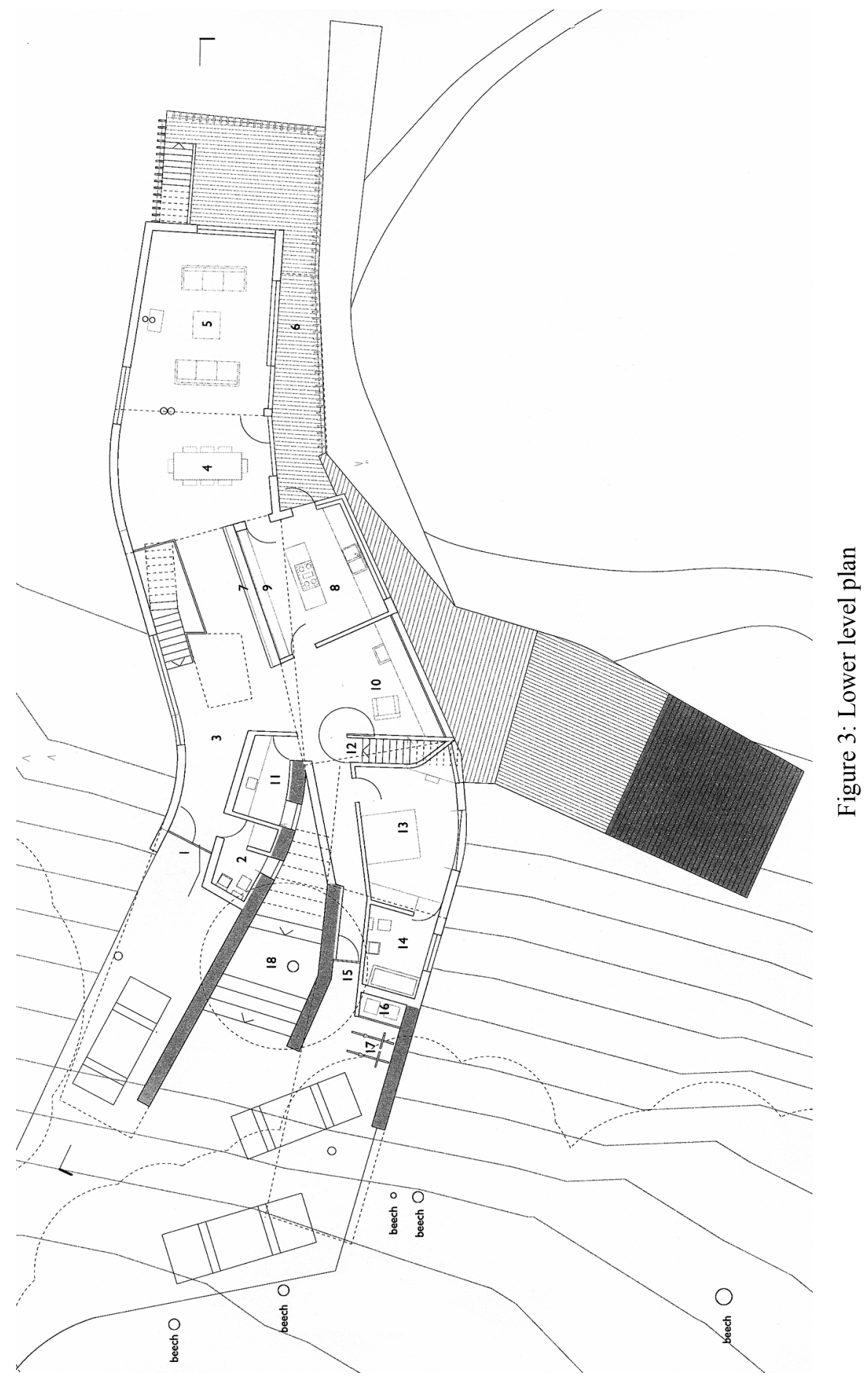

WIT Transactions on The Built Environment, Vol 86, (c) 2006 WIT Press

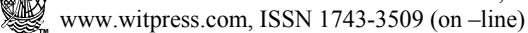


The design of the house presents ample space for well-lit offices and a library. Particular attention has been paid to the orientation of the rooms in order to maximize solar heating and ventilation.

\section{Environmental engineering}

The design proposal by Max Fordham was to produce an ecology-efficient building.

Their prime concern was to achieve a low energy building by reducing energy delivery inefficiencies. To this end they have proposed:

- To avoid gas and oil-fired heating through super insulation and maximizing useful solar gain.

- To avoid the need for space cooling through careful consideration of building orientation, fabric design and effective natural ventilation.

- Generate sufficient electricity on site from photovoltaic cells to meet the demands of the building.

- Generate solar-heated hot water from roof-mounted panels.

- To use rainwater for WC flushing to minimize potable water consumption.

- To treat wastewater on site as far as practicable.

\subsection{Temperature control in the winter}

The house is expected to have a heat loss in the order of $20,000 \mathrm{kWh} / \mathrm{annum}$. The majority of the space heating will be provided through useful solar gains (approximately 16,000kWh/annum over the South and South West orientations). Heat gains from occupants (in the order of $1000 \mathrm{kWh} /$ annum) and other internal gains from white goods etc. (in the order of $2500 \mathrm{kWh} /$ annum).

In extreme weather conditions, some supplementary heating may be required. In order to avoid gas or oil-fired heating, which would directly produce $\mathrm{CO}_{2}$ and $\mathrm{NO}_{\mathrm{x}}$ as well as requiring significant infrastructure to the site, the use of a Ground Source Heat Pump (GSHP) is preferred.

A properly designed GSHP installation would be expected to produce approximately half of the $\mathrm{CO}_{2}$ emissions of a similar gas-fired, condensing boiler. A typical Coefficient of Performance (COP) is 3 to 4 meaning that for a $2.5 \mathrm{~kW}$ electrical input, 7.5 to $10 \mathrm{~kW}$ of heat energy is produced. This is compared to a best COP of 0.9 for a gas-fired boiler. Electrical energy used to power the heat pump will be offset by that generated on-site by the photovoltaic cells.

The heat pump works on the principle of moving heat energy from a heat source to a heat sink, it being more efficient to transfer existing heat energy than to generate new. 
Eco-Architecture: Harmonisation between Architecture and Nature 221

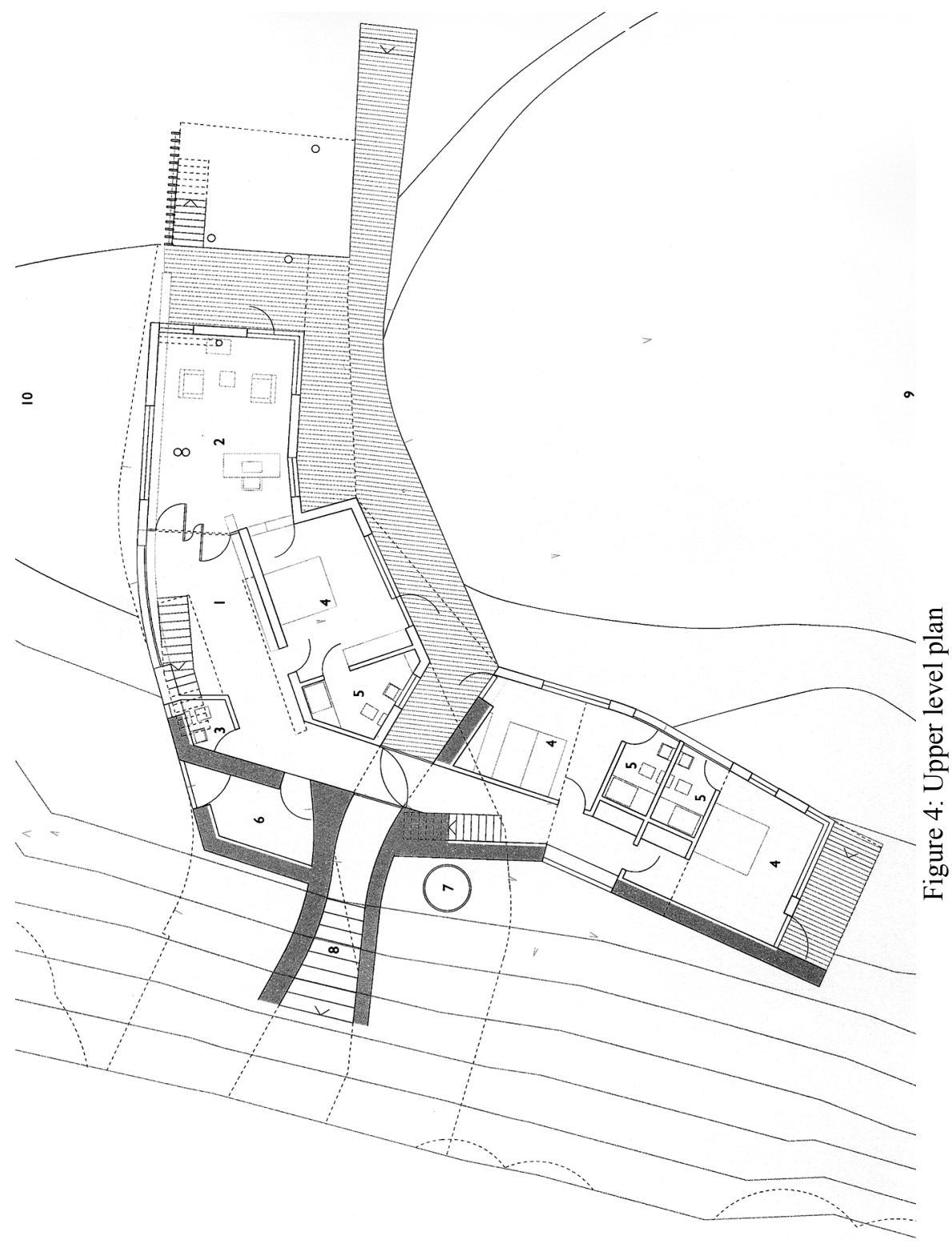


A refrigeration circuit in the heat pump transfers low grade heat at the 'source' (typically 5 to $10^{\circ} \mathrm{C}$ ) to a higher grade heat (typically 35 to $45^{\circ} \mathrm{C}$ ) for use in the heat 'sink'.

In the case of the Burley Hill House, the heat 'source' will be the lake and the 'sink', the house. By using the lake, the ground source heat pump efficiency is increased since ground with a high moisture content offers superior heat transfer. Pipework loops will be installed on the bottom of the lake meaning they can be easily removed if decommissioning the house. As the lake has an approximate volume of $600 \mathrm{~m}^{3}$, the heat pump is of insufficient size to alter the temperature of the water significantly.

GSHP installations operate best with underfloor heating installations, since the water temperatures are far lower than those used in traditional 'radiator' systems. Underfloor systems also offer the advantage of heating the surfaces, rather than the air above the occupied zone, offering a reduction in heat input requirements. Underfloor heating will be installed throughout the building, but its use is expected to be minimal.

Wood stoves located within communal living areas will provide a focal point to the room. They will also offer a carbon neutral method of heating as the fuel will be supplied from the woodland trimmings from the surrounding estate, as part of the existing forestry maintenance scheme. Furthermore, by specifying units with integral heat exchangers, we plan to preheat the domestic hot water installations when the stoves are in use.

Space temperature control will be optimized by an intelligent Building Energy Management System (BEMS) which will include weather compensation, optimum start/stop and night/holiday set back.

Guest rooms will be maintained at $12^{\circ} \mathrm{C}$ when not in use through winter to prevent condensation. The BEMS will ensure that useful solar and internal heat gains are maximized before operating the heat pump.

\subsection{Temperature control in the summer}

The architectural design ensures that the building form does not cause uncomfortable summer time temperatures, a problem which is becoming more common with modern building construction. A shadowing strategy has been adopted to cut out the direct radiant component of the higher summer sun. Shading has been carefully designed so that whilst it avoids solar gain during the summer, it does not prohibit useful solar gain when the sun is at a lower altitude during the winter months. We anticipate that the surrounding deciduous trees will also help in this respect. High performance glazing will be installed to further reduce heat gains to the space from diffuse solar radiation.

Ventilation will play a key part in maintaining a comfortable summer environment. Passive stack ventilation will be employed where a useful height differential exists to exploit the properties of warm, buoyant air. Elsewhere, the window design will offer sufficient area for good single-sided or cross flow ventilation of rooms. 
Generally, natural ventilation of all rooms will be encouraged, however where activities resulting in high moisture output take place (such as shower rooms and the kitchen) supplementary rapid extraction will be provided. In these locations, fans will operate on a humidity sensor to minimize operating time.

\subsection{Generation of electricity}

Although renewable wind technologies offer the potential to produce greater quantities of electrical energy, they would not be appropriate in this particular location. The visual appearance and the impact on the local environment would not be in keeping with the ethos of this project.

Therefore, solar photovoltaic panels were selected to generate on-site energy. Approximately $22 \mathrm{~m}^{2}$ of photovoltaic cells will be installed on the roof of Burley Hill House, the orientation and mounting angle selected in order to optimize solar gain. We anticipate the solar panels will generate a peak output of $2 \mathrm{~kW}$ giving an annual output in the order of $1650 \mathrm{kWh}$, which is the estimated annual demand for the house. This will save $710 \mathrm{~kg}$ of $\mathrm{CO}_{2}$ when compared to the same quantity of electrical energy supplied from the national grid, and effectively make the house carbon neutral.

When energy generation exceeds demand in the summer, electricity will be sold back to the grid, using the grid as a 'battery' for times of little or no sun and when artificial lighting is required at night. In order to facilitate this, an electrical supply is unavoidable. The cable route will be carefully traced to avoid disturbance to the local environment as far as possible.

Natural daylight will be maximized throughout the building in order to reduce the reliance of the occupants on artificial lighting. Low-energy light fittings will be selected throughout, with appropriate control strategies employed to avoid unnecessary use.

\subsection{Solar hot water heating}

Roof-mounted, high efficiency solar water heating panels will be installed in order to provide domestic hot water to the house. During the summer, all of the hot water requirements of showering etc. will easily be met by the solar panels. When the sky is overcast, some solar radiation will still be present and this will be used to 'pre-heat' the hot water cylinder. Further water heating will be provided by the wood-fired stoves when they are in use.

By installing $2 \mathrm{~m}^{2}$ of solar panels, $2000 \mathrm{kWh}$ of heat output per annum will be produced, representing over $50 \%$ of the hot water requirement.

\subsection{Water conservation}

Rainwater harvesting and storage will be provided to flush all WCs. On average, a typical two-person dwelling consumes over 28,000 litres of water per year, just to flush WC pans. Preliminary calculations suggest we could collect over 100,000 litres of rain per year, negating the need to flush potable water through a toilet. 
It may be possible to investigate using spring water for drinking purposes. At present, a mains supply will be required. However, low flow fittings will be specified throughout to reduce demand, and as stated above, mains water will not normally be used to flush WCs.

\subsection{Waste water}

Because of the isolated location, there are no public sewers to which we could discharge sewage and waste water. Common practice is to either provide a cesspit (which requires frequent emptying by road tanker) or by septic tank coupled with a soak away. As the soil type is predominately clay, a drainage soak away is not feasible.

Sewage treatment will be provided on site by coupling a septic tank with a purpose made, horizontal reed bed. In this way, waste water can be treated to a safe level, allowing it to be discharged into the lake after passing through the reed bed. Reed bed installations are increasingly common and provide a natural means of treating water, reducing the burden on sewage treatment plants. Although the septic tank will require de-sludging on a four year basis, the environmental impact of such a scheme is small.

Natural evaporation of the lake should regulate its level throughout the year. However, sometimes it 'overflows' to a drainage ditch, which in turn, discharges into a local river. Dialogue has been established with the local offices of the Environment Agency to ensure the compliance of the scheme.

\section{The structure}

The proposed new building will be of lightweight construction with a timber frame. It is therefore, planned that the foundations will need to support point loads from the posts in the timber frame.

The key factors influencing the design of the foundations were the need to minimize construction in the ground, the desire to avoid using concrete, the relatively light point loads to be supported and the nature of the ground.

The Structural Engineers proposed the use of galvanized steel screw piles to respond to all these concerns.

These comprise steel augers which are screwed into the ground to a depth determined by detailed consideration of the soil properties. The principle is similar to that by which in-situ concrete piles are formed, except that the auger is not extracted and replaced with concrete. The auger is left in the ground and the loads from the new structure are applied to the shaft of the auger once the machinery for screwing it into the ground has been removed. It is possible to remove the piles by simply reversing the machinery and unscrewing them. The selection of a diameter and working length for a pile is a matter for the detailed design stage, but is it expected that screws with a diameter of $200-300 \mathrm{~mm}$ will be selected. 
The impact on the ground is minimal. The piles are conventionally installed with rotating machinery that is attached to the back-acter of a light wheeled tractor. The whole system has been used successfully elsewhere in environmentally sensitive situations.

\section{Conclusions}

This paper describes the design for an eco-house put forward by James Gorst Architects on behalf of the owner of the site, Professor Carlos Brebbia, both coauthors of this paper.

The brief was to design an outstanding piece of architecture that satisfies the requirements of the owner. Equally important was, for the building to be energy efficient and to harmonize with its environment.

The proposed design has been the result of a team effort involving planning consultants, landscape architects, ecologists, environmental and structural engineers as well as the architect himself.

Close collaboration between the different partners as well as the owner was required to achieve all the requirements.

The authors believe that an optimal solution has been found of outstanding architectural and engineering merit. Designs like this are essential to point the way to the future.

\section{Acknowledgements}

The authors would like to acknowledge the contributions of other members of the design team, in particular:

Hilary Martin, Landscape Architect.

Ian Smith, of Max Fordham LLP.

Chris Corcoran, Southern Planning Practice Ltd.

Robert Bowler of Alex Baxters and Associates.

Their close collaboration with James Gorst Architects has resulted in the design described in this paper.

\section{References}

[1] McCloud, K “Grand Designs Abroad. Building your team.” Collins, London, 2004.

[2] Roaf, S. "Closing the Loop. Benchmarks for Sustainable Buildings". RIBA Enterprises, London 2004.

[3] Ecohomes Scheme, British Research Establishment, Watford, 2005.

[4] Wilhide, I., 'Eco' Quadrille Publishing, London, 2002.

[5] Roaf, S., 'Ecohouse 2: A Design Guide' Elsevier, Amsterdam, 2003. 